\title{
Survival of allochthonous bacteria in still mineral water bottled in polyvinyl chloride (PVC) and glass
}

\author{
Leonilde Moreira, Paula Agostinho, Paula Vasconcellos Morals and M. S. da Costa \\ Departamento de Bioquímica, Instituto de Investigação da Água, Universidade de Coimbra, Coimbra, Portugal
}

4761/12/93: accepted 15 April 1994

L. MOREIRA, P. AGOSTINHO, P. V. MORAIS AND M. S. DA COSTA. 1994. The mortality of Escherichia coli, Enterobacter cloacae, Klebsiella pneumoniae and $P$ seudomonas aeruginosa, based on the culturability of these bacteria, was assessed in non-carbonated mineral water, bottled in polyvinyl chloride (PVC) containing the indigenous flora, sterile mineral water bottled in PVC, sterile mineral water in glass containers, and sterile tap water in glass containers. There was a general decrease in the culturability of these organisms in the four test waters, except that $P$ s. aeruginosa grew in sterile tap water. Escherichia coli and $K l$. pneumoniae had the highest mortality rates under the conditions tested, while Ent. cloacae had a very low and constant mortality rate that would have resulted in the persistence of this organism in mineral water for a long period of time. After a sharp initial decrease in culturability, Ps. aeruginosa also had a very low mortality rate in mineral water bottled in PVC.

\section{INTRODUCTION}

Information about the survival capacity of bacterial indicators of faecal pollution and pathogenic bacteria in different water habitats is crucial to public health for the evaluation of possible risks. Coliforms and faecal coliforms are used as indicators of water quality and the absence of these bacteria as culturable cells is an indication of good quality water (Anon. 1981).

The bacteriological quality of bottled mineral water is based on the presence/absence of indicator bacteria for faecal pollution (Escherichia coli, faecal streptococci and sporulating sulphite-reducing anaerobes), surface water contaminants (total coliforms, sporulating sulphite-reducing anaerobes) and pathogenic bacteria such as Pseudomonas aeruginosa (Anon. 1980). The data available on the survival of bacteria in superficial waters cannot be extrapolated to bottled mineral waters and several workers who studied the survival of bacteria recognized the impact of experimental bottling stress on the population dynamics of these organisms (Flint 1987; Overbeek et al. 1990; Barcina et al. 1990; Korhonen and Martikainen 1991). The chemical and microbiological characteristics of mineral waters can also affect allochthonous bacteria in different ways (SchmidtLorenz 1976). In bottled mineral water allochthonous bacteria must cope with an enclosed environment of very low

Correspondence to: Paula Vasconcellos Morais, Departamento de Bioquimica, Universidade de Coimbra, Apartado 3126, 3000 Coimbra, Portugal. nutrient content and interact with the autochthonous population present in the bottle, which can reach considerable numbers a few days after storage (Morais and da Costa 1990; Hunter 1993). To understand the significance of the presence of coliforms or $P_{s}$. aeruginosa in bottled mineral water it is necessary to determine the survival capacity of these bacteria in water bottled in different types of containers during normal storage conditions.

Bottled water can occasionally become contaminated with bacteria, some of which could be pathogens, indicators of surface water contamination or of faecal contamination. Although the aquifer of a bottled mineral water can become contaminated, the bottling system is the most likely source of contamination. EC directives (Anon. 1980) recommend the microbiological quality control of bottled mineral water only immediately after bottling. Among other considerations, this would be the most likely time to detect indicators of faecal pollution or pathogenic bacteria, because of the presumed mortality of some of these organisms in bottled water. Furthermore, high heterotrophic plate counts of autochthonous bacteria after storage of bottled water can interfere with the detection indicators of faecal pollution (Geldreich et al. 1975; Lamka et al. 1980). In this study the survival of Escherichia coli, Enterobacter cloacae, Klebsiella pneumoniae and Pseudomonas aeruginosa were determined in a bottled still mineral water in the presence and absence of the autochthonous bacterial flora. The influence of the bottling material (polyvinyl chloride or glass) on 
the survivorship of the allochthonous bacteria was also investigated.

\section{MATERIALS AND METHODS}

\section{Test strains}

The test strains used were $E$. coli (ATCC 8677), Ent. cloacae (ATCC 13047), Kl. pneumoniae (ATCC 13833) and Ps. aeruginosa (ATCC 27853), obtained from American Type Culture Collection (Rockville, MD, USA) and maintained at $-80^{\circ} \mathrm{C}$ in Tryptic Soy Broth (TSB, Difco) plus $15 \%(\mathrm{v} / \mathrm{v})$ glycerol.

\section{Preparation of microcosms}

Tap water was obtained from the public water distribution system of Coimbra. The mineral water used was collected at a still mineral water bottling plant in Central Portugal and had the following physical and chemical characteristics: temperature at the source, $27^{\circ} \mathrm{C} ; \mathrm{pH}, 5.64$; conductivity, $5.44 \times 10^{-5} \mathrm{Ohm}^{-1} \mathrm{~cm}^{-1}$; dry residue at $180^{\circ} \mathrm{C}, 42.2 \mathrm{mg}$ $1^{-1}$; dissolved oxygen, $0.4 \mathrm{mg} 1^{-1}$; and free $\mathrm{CO}_{2}, 50 \mathrm{mg}$ $1^{-1}$.

The four test waters were prepared as follows:

(1) Mineral water in PVC bottles with autochthonous flora. Mineral water in $330 \mathrm{ml}$ polyvinyl chloride (PVC) bottles was obtained immediately after bottling in factory and maintained at room temperature $\left( \pm 22^{\circ} \mathrm{C}\right)$ in the dark for 3 months to allow the autochthonous flora to reach high numbers before inoculating the test strains. Mineral water was examined for the presence of coliforms by membrane filtration on m-Endo LES (Difco) and Ps. aeruginosa on Cetrimide Agar (Difco) of $250 \mathrm{ml}$ of water (Anon. 1981).

(2) Sierile mineral water in PVC bottles. Empty PVC bottles $(330 \mathrm{ml})$ were capped with ethylene-oxide sterilized polyethylene caps immediately after production. Sterility of PVC bottles was assessed by shaking the bottles with $5.0 \mathrm{ml}$ of sterile phosphate dilution buffer (Anon. 1985). The number of colony-forming units (cfu) was determined in $1.0 \mathrm{ml}$ by the pour plate method on Plate Count Agar (Anon. 1985) after incubation of the plates at $22^{\circ} \mathrm{C}$ for $72 \mathrm{~h}$ and at $37^{\circ} \mathrm{C}$ for $24 \mathrm{~h}$. Mineral water was sterilized through $0.2 \mu \mathrm{m}$ pore size nylon filters (Pall Ultipore, Portsmouth, UK) and then placed in a boiling water bath for $20 \mathrm{~min}$ (Colbourne et al. 1988). Sterility of the mineral water was assessed as described above.

(3) Sterile mineral water in glass containers. Glass-stoppered Pyrex Erlenmeyer flasks $(300 \mathrm{ml})$ were washed overnight with concentrated $\mathrm{HCl}(37 \%)$, followed by a wash in perchloric acid $(70 \%)$ for $24 \mathrm{~h}$. The flasks were then rinsed several times with hot tap water, deionized water and three times in ultra pure water (Millipore). The flasks and the glass stoppers were heated overnight at $250^{\circ} \mathrm{C}$, cooled and covered with sterile aluminium foil. The flasks were filled with sterile mineral water, prepared as described above, immediately before inoculation with the test strains.

(4) Sterile tap water in glass containers. Sterile glass stoppered Pyrex flasks, prepared as above, were filled with filtered and heated tap water as described above for mineral water.

\section{Survival experiments}

The test strains were grown with shaking in a basal medium containing $\left(\mathrm{g}^{-1}\right)$ : yeast extract, 0.76 ; $\mathrm{K}_{2} \mathrm{HPO}_{4}, 15 \cdot 1 ;\left(\mathrm{NH}_{4}\right)_{2} \mathrm{SO}_{4}, 2 \cdot 2 ; \mathrm{MgSO}_{4} \cdot 7 \mathrm{H}_{2} \mathrm{O}, 0.2$; $\mathrm{FeSO}_{4} \cdot 7 \mathrm{H}_{2} \mathrm{O}, 6.0 \mathrm{mg} \mathrm{l}^{-1}$; pH 6.8 (Pastan and Perlman 1968) supplemented with $2 \cdot 0 \%$ glucose at $37^{\circ} \mathrm{C}$ until the cultures reached 0.5 O.D. units at $610 \mathrm{~nm}$ (Milton Roy Spectrophotometer 601, Milton Roy, Stafford, UK), harvested by centrifugation $\left(2000 \mathrm{~g}\right.$ ) for $10 \mathrm{~min}$ at $4^{\circ} \mathrm{C}$, and washed twice with sterile mineral water.

The washed suspensions were inoculated into flasks containing sterile mineral water and maintained for $24 \mathrm{~h}$ at $25^{\circ} \mathrm{C}$ in the dark. The starved bacterial cells were inoculated in duplicate in the four test waters to give the final suspension of about $10^{5}$ colony-forming units (cfu) $\mathrm{ml}^{-1}$ determined by plate count (see below). The inoculated test waters were maintained at $25^{\circ} \mathrm{C}$ in the dark, without shaking, for the experimental period. Two independent experiments were performed in duplicate for each microcosm.

\section{Vlabillty determinations}

Samples or dilutions of the experimental waters containing the test bacteria were spread in triplicate on Tryptic Soy Agar (TSA, Difco), and incubated at $37^{\circ} \mathrm{C}$ for $24 \mathrm{~h}$. Phosphate buffer dilution water, $\mathrm{pH} 7 \cdot 2$, was used for dilution of the test and endogenous bacteria for viable counts (Anon. 1985). Presumptive coliform colonies were confirmed by production of gas in brilliant green bile broth (Anon. 1985). Pseudomonas aeruginosa colonies were confirmed by hydrolysis of casein and the production of pyoverdin and pyocyanin on Skim Milk Agar (Difco) after incubation at $30^{\circ} \mathrm{C}$ for $48 \mathrm{~h}$ (Havelaar et al. 1985).

The endogenous bacterial flora of the mineral water was enumerated preparing all samples and decimal dilutions in phosphate buffer dilution water. Samples or dilutions $(0 \cdot 1$ ml) were spread plated in triplicate on $R_{2} A$ Agar (Reasoner and Geldreich 1985). The plates were incubated in plastic bags in humidified incubators at $22^{\circ} \mathrm{C}$ for $15 \mathrm{~d}$. 


\section{Data analysis}

The experimental results were fitted with a theoretical model of the kinetics of cell death under starvation conditions described by:

$$
\mathrm{d} N / \mathrm{d} t=k N^{\alpha+1}
$$

where $N$ is the number of viable cells at time $t$, and $k$ and $\alpha$ are constants (Kumada et al. 1985). This equation was obtained by making the growth constant dependent on $N$ where $K(N)=k N^{\alpha}$. To adjust the mortality curves, we used the equation for the initial conditions where $N=N_{0}$ and $t=t_{0}$ because it minimizes errors during the calculations of the mortality rates. With the same equation, $k$ and $\alpha$ were calculated by non-linear adjustment by the method of least-squares. The mortality rate was calculated as $\mathbf{d}=k N^{\alpha}$.

\section{RESULTS}

The mineral water samples used in this study contained no coliforms or Ps. aeruginosa in $250 \mathrm{ml}$. The coliform bacteria and $P_{s}$. aeruginosa added to the test waters were easily detected in the presence of the indigenous bacteria because, within the first $24 \mathrm{~h}$ at $37^{\circ} \mathrm{C}$, only the test bacteria formed visible colonies on TSA. During the experimental period
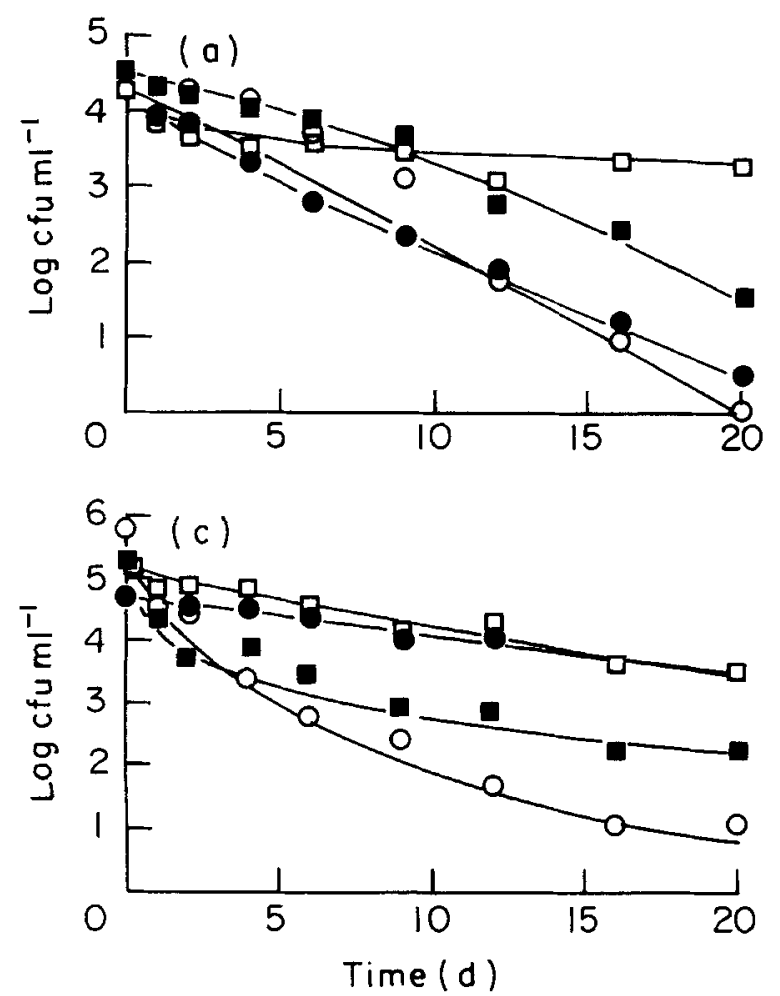

the heterotrophic plate counts (HPC) of the indigenous bacteria of the bottled mineral water (test water 1 ) varied between $1.09 \times 10^{5} \mathrm{cfu} \mathrm{ml}^{-1}$ and $1.03 \times 10^{6} \mathrm{cfu} \mathrm{ml}^{-1}$ at $22^{\circ} \mathrm{C}$ and there was no indication that the allochthonous bacteria had any effect on the indigenous population.

The viable counts of the three test enterobacteria decreased under all experimental conditions, but the decrease depended on the organism and the conditions in which they were examined. The population of $E$. coli decreased rapidly in mineral water, especially in mineral water bottled in PVC irrespective of the presence or absence of autochthonous bacterial flora. In sterile tap water, after an initial decrease, the viable counts remained almost constant during the experimental period (Fig. 1a).

Of the three enterobacteria tested, Ent. cloacae had the slowest decrease in viable counts in any of the conditions, although the decrease in viable counts was slightly more pronounced in sterile mineral water bottled in PVC than in the other test conditions (Fig. 1b).

A small constant decrease in the viable counts of $K l$. pneumoniae was observed in mineral water bottled in PVC with indigenous flora and in sterile tap water. On the other hand, this strain was rapidly inactivated in sterile mineral water bottled in PVC and glass resulting in very low viable counts after the $20 \mathrm{~d}$ experimental period (Fig. 1c).
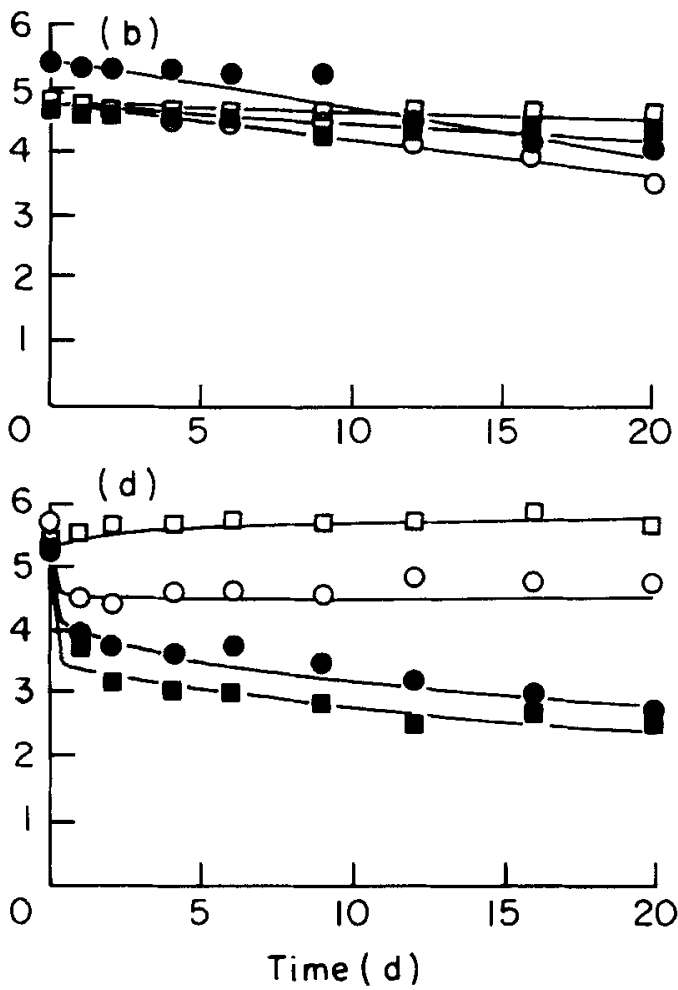

Fig. 1 Survival determined by viable counts (mean of two independent experiments) on tryptic soy agar of (a) Escherichia coli, (b) Enterobacter cloacae, (c) Klebsiella pneumoniae and (d) Pseudomonas aeruginosa inoculated in mineral water in PVC bottles with autochthonous flora $(O)$, in sterile mineral water in PVC bottles $(O)$, in sterile mineral water in glass containers $(\square)$ and in sterile tap water in glass containers ( $\square$ ) 
In contrast to the other test bacteria, $P$ s. aeruginosa grew in tap water. Immediately after inoculation of this organism in mineral water there was a sharp decrease in the viable counts. Afterwards, there was a very slow decrease in viable counts in PVC bottled mineral water with autochthonous flora and sterile mineral water in glass containers, but the viable counts in sterile mineral water bottled in PVC remained constant for the duration of the experiment (Fig. 1d).

The theoretical curves calculated from eqn 1 fit the experimental results, and described the bacterial survival during starvation. For each bacterium, in each microcosm, the mortality rate varied, either decreasing or increasing during the experimental period.

The mortality rates of $E$. coli in mineral water microcosms were very similar and they were almost constant during the experimental period (Fig. 2a). On average it had the highest mortality rate of all allochthonous bacteria, although in tap water $E$. coli showed a high initial mortality rate followed by a low mortality rate which was similar to other enterobacteria in tap water.

Enterobacter cloacae had a low and almost constant mortality rate during the experimental period in all microcosms (Fig. 2b). The behaviour of $K l$. pneumoniae was different from that of the other allochthonous bacteria examined, showing a high mortality rate immediately after being inoculated in sterile mineral water followed by a sharp decrease in the mortality rate after this initial shock. On the other hand, the mortality rate of $\mathrm{Kl}$. pneumoniae was very low and constant in the presence of the autochthonous bacterial flora of the mineral water (Fig. 2c).

Pseudomonas aeruginosa had a high mortality rate immediately after inoculation in mineral water with flora and in mineral water bottled in washed glass but, afterwards, the mortality rates decreased almost to zero in all the mineral water microcosms (Fig. 2d). When inoculated in tap water $P$ s. aeruginosa had a negative mortality rate, which showed that this organism grew under the experimental conditions.

\section{DISCUSSION}

This study demonstrates that, in general, the test bacteria examined show a progressive decrease in culturability in mineral water bottled in glass or PVC. The results do not rule out the existence of viable cells in a non-culturable state. However, microbiological quality control relies on the culturability of bacteria on selective media, and not on the determination of viability by staining methods. The utilization of selective media would, no doubt, have a more pronounced effect on the culturability than the nonselective medium used here.

The capacity of survival of organisms under stress conditions depends, among other factors, on the age of the cultures. In this study all organisms were grown until the early
Fig. 2 Mortality rate $\left(\mathrm{d}=N^{\alpha}\right)$ at 1,10 and $20 \mathrm{~d}$ during the experimental period of (a) Escherichia coli, (b) Enterobacter cloacae, (c) Klebsiella pneumoniae and (d) Pseudomonas aeruginosa inoculated in mineral water in PVC bottles with autochthonous flora ( $\square$ ), in sterile mineral water in PVC bottles (W), in sterile mineral water in glass containers (国), and in sterile tap water in glass containers
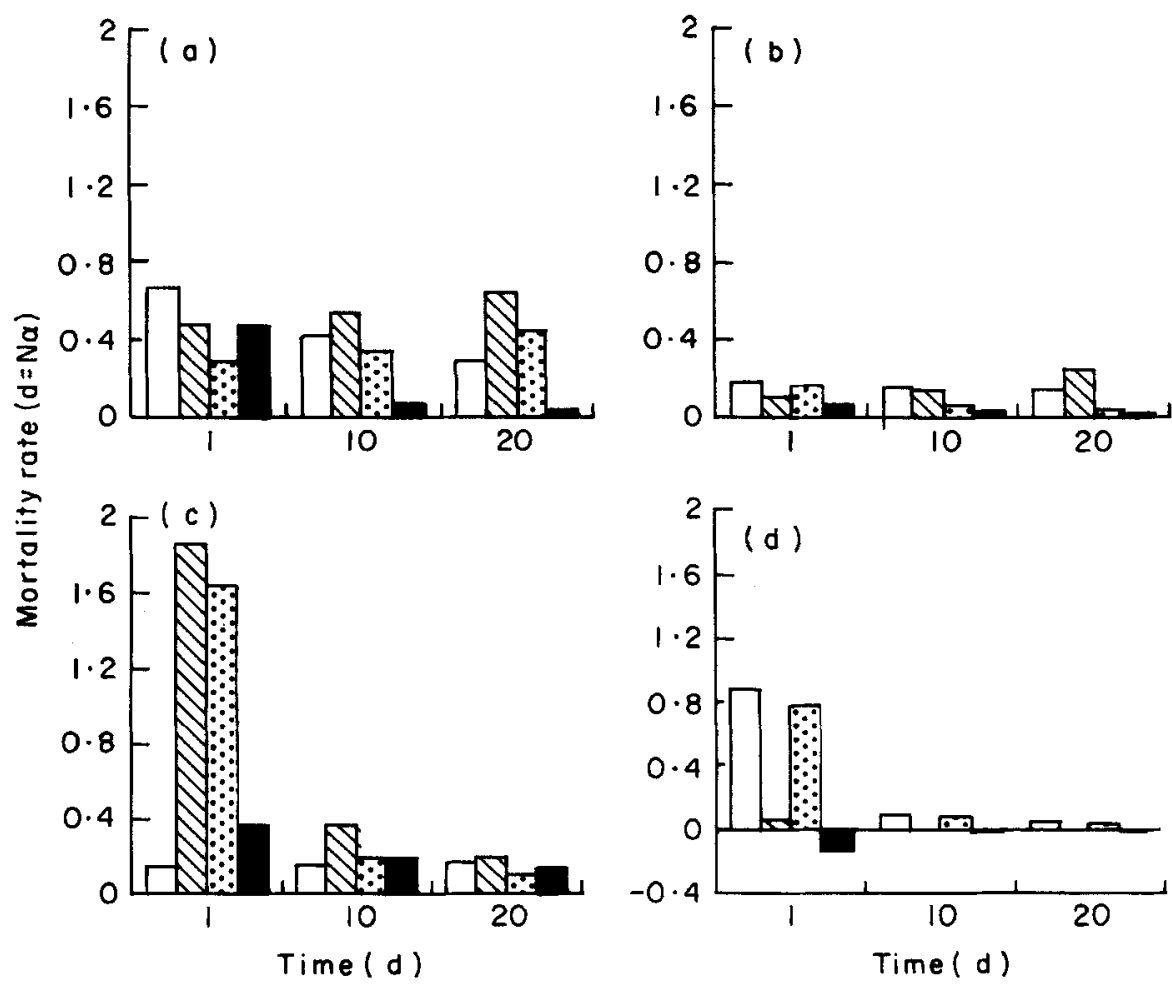
stationary phase of growth, which previous studies show to be the most resistant phase of growth of $E$. coli and $K l$. pneumoniae to survival in water (LeChevallier et al. 1988; Gauthier et al. 1992). The initial starvation of the test organisms was designed to deplete the bacteria of nutrient carryover and minimize the possibility of regrowth under the experimental conditions.

A limited number of studies on the survival of faecal indicator organisms and pathogens in mineral water show marked discrepancies that are probably due to different test conditions, and different chemical and microbiological parameters of the mineral waters. In one study, $10^{7} \mathrm{cfu}$ $\mathrm{ml}^{-1}$ of $E$. coli inoculated in a gas-free mineral water became undetectable within $4 \mathrm{~d}$ but the addition of a small amount of faeces to the bottled mineral water enhanced the survival of $E$. coli to several weeks (Ducluzeau et al. 1976). Another study reported that $E$. coli declined by 1 log every 2 weeks in sterile spring water stored at $4^{\circ} \mathrm{C}$ (Karapinar and Gönül 1991). Mineral waters, however, are not generally stored at this temperature during transport and at retail outlets. In this study the decrease in culturability of coliform bacteria depended on the type of water (mineral or tap), the presence or absence of the normal flora of the mineral water and the type of container used (PVC or glass). While $E$. coli is the canonical indicator of faecal pollution, coliforms such as $K l$. pneumoniae and Ent. cloacae are commonly found in tap water (Gavini et al. 1985) and are capable of growth in drinking water systems (Camper et al. 1991; Stewart and Olson 1992). The presence of the latter organisms in mineral water may not signify faecal contamination but clearly indicates that the aquifer and/or the bottling system are contaminated with non-mineral water sources. In this study Ent. cloacae had very low mortality rate and would have persisted in the mineral water for a long period of time irrespective of the test conditions. Pseudomonas aeruginosa is frequently isolated from water and several studies show it to grow even under conditions of very limited nutrient content (van der Kooij et al. 1982). It is also a major concern in mineral water bottling plants, and has been isolated from bottled mineral water which had already been removed from market (Manaia et al. 1990).

The autochthonous bacteria of mineral water have been reported to have an inhibitory effect on the survival of $E$. coli (Lucas and Ducluzeau 1990). In the present study, however, the autochthonous flora of the mineral water, which reached $1.03 \times 10^{6} \mathrm{cfu} \mathrm{ml}^{-1}$ during the experimental period did not appear to have an effect on the survival of $E$. coli and Ent. cloacae, but it did appear to have a negative effect on the survival of $P_{s}$, aeruginosa and a positive effect on the survival of $K l$. pneumoniae compared to the other conditions tested.

The initial sharp decrease in culturability of $P_{s}$. aeruginosa in mineral water with the bacterial flora in PVC, in sterile mineral water in glass, as well as the initial decrease of $K \dot{K l}$. pneumoniae in sterile mineral water can perhaps be attributed to a requirement for a period of physiological adaptation to stress conditions (Morita 1982; Roszak and Colwell 1987; Matin et al. 1989) after which the mortality rate decreases.

The type of container did not influence the survival capacity of the enterobacteria tested, but Ps. aeruginosa had a lower mortality rate in water bottled in PVC that may reflect the capacity of this bacterium to colonize this type of material (Vess et al. 1993). It has also been shown that the colonization of surfaces enhances the capacity of bacteria to resist disinfection and starvation (Fletcher and Marshall 1982; LeChevallier et al. 1988; Geesey and White 1990). In this study $P s$. aeruginosa also showed a high degree of survivorship in mineral water bottled in PVC.

For every organism examined the mortality rate was lower in tap than in mineral water and $P_{s}$. aeruginosa even grew in tap water. This difference can be due only to differences in the chemical composition or in the carbon content of the waters.

This study confirms EC regulations that mandate the microbiological quality control of mineral water immediately after bottling, since the absence of $E$. coli several days after bottling is not proof that faecal contamination has occurred during bottling. The need for the microbiological testing of coliforms in bottled mineral water is important because organisms such as Ent. cloacae and $K l$. pneumoniae will survive for very long periods of time, and their presence indicates contamination with surface water, even in the absence of faecal pollution, and may therefore indicate the presence of pathogens in the mineral water.

In view of the multiplication and growth of some organisms, in particular Ps. aeruginosa in water, it is important to conduct more studies into the survival and growth of potential waterborne pathogens to ensure the high quality and safety of bottled still mineral waters.

\section{ACKNOWLEDGEMENTS}

This study was supported in part by the Sociedade das Águas de Luso, SA. We also thank Dr João Brandão for his help with the mathematical analysis of the results.

\section{REFERENCES}

Anon. (1980) Directive du conseil du Juillet 1980 relative au rapprochement des législation des états membres concernant l'exploitation et la mise dans le commerce de eaux minérales naturelles (80/777/CEE). Journal Officiel des Communautès Européenes L229, 1-10.

Anon. (1981) Report of the Fourth FAO/WHO Working Group on the establishment and application of microbiological criteria 
for foods, dried milk products and natural mineral waters. VPH/81.32. Washington, DC: Food and Agriculture Organization.

Anon. (1985) Standard Methods for the Examination of Water and Wastewater, 16th edn. pp. 827-917. Washington, DC: American Public Health Association.

Barcina, I., González, J.M., Iriberri, J. and Egea, L. (1990) Survival strategy of Escherichia coli and Enterococcus faecalis in illuminated fresh and marine systems. Journal of Applied Bacteriology 68, 189-198.

Camper, A.K., McFeters, G.A., Characklis, W.G. and Jones, W.L. (1991) Growth kinetics of coliform bacteria under conditions relevant to drinking water distribution systems. Applied and Environmental Microbiology 57, 2233-2239.

Colbourne, J.S., Trew, R.M. and Dennis, P.J. (1988) Treatment of water for aquatic bacterial growth studies. Journal of Applied Bacteriology 65, 79-85.

Ducluzeau, R., Hudault, S. and Galpin, J.V. (1976) Longevity of various bacterial strains of intestinal origin in gas-free mineral water. European Journal of Applied Microbiology 3, 227-236.

Fletcher, M. and Marshall, K.C. (1982) Are solid surfaces of ecological significance to aquatic bacteria? In Advances in Microbial Ecology ed. Marshall, K.C. Vol. 6, pp. 199-236. New York: Plenum Press.

Flint, K.P. (1987) The long-term survival of Escherichia coli in river water. Journal of Applied Bacteriology 63, 261-270.

Gauthier, M.J., Flatau, G.N., Clément, R.I. and Munro, P.M. (1992) Sensitivity of Escherichia coli cells to seawater closely depends on their growth stage. Journal of Applied Bacteriology $73,257-262$.

Gavini, F., Leclerc, H. and Mossel, D.A. (1985) Enterobacteriaceae of the "Coliform group" in drinking water: identification and worldwide distribution. Systematic and Applied Microbiology 6, 312-318.

Geesey, G.G. and White, D.C. (1990) Determination of bacterial growth and activity at solid-liquid interfaces. Annual Review of Microbiology 44, 579-602.

Geldreich, E., Nash, D., Reasoner, J. and Taylor, H. (1975) The necessity of controlling bacterial populations in potable waters Bottled water and emergency water supplies. Journal of American Water Works Association 67, 117-124.

Havelaar, A.H., During, M. and Delfgou-van Asch, E.H. (1985) Comparative study of membrane filtration and enrichment media for the isolation and enumeration of Pseudomonas aeruginosa from sewage, surface water, and swimming pools. Canadian Journal of Microbiology 31, 684-692.

Hunter, P.R. (1993) The microbiology of bottled natural mineral waters. Journal of Applied Bacteriology 74, 345-352.

Karapinar, M. and Gönül, S.A. (1991) Survival of Yersinia enterocolitica and Escherichia coli in spring water. International Journal of Food Microbiology 13, 315-320.

Korhonen, L.K. and Martikainen, P.J. (1991) Survival of Escherichia coli and Campylobacter jejuni in untreated and filtered lake water. Journal of Applied Bacteriology 71, 379-382.

Kumada, K., Koike, K. and Fujiwara, K. (1985) The survival of bacteria under starvation conditions: a mathematical expression of microbial death. Journal of General Microbiology 131, 23092312.

Lamka, K.G., LeChevallier, M.W. and Seidler, R.J. (1980) Bacterial contamination of drinking water supplies in a modern rural neighborhood. Applied and Environmental Microbiology 39, 734-738.

LeChevallier, M.W., Cawthon, C.D. and Lee, R.G. (1988) Factors promoting survival of bacteria in chlorinated water supplies. Applied and Environmental Microbiology 54, 649-654.

Lucas, F. and Ducluzeau, R. (1990) Antagonistic role of various bacterial strains from the autochthonous flora of gas-free mineral water against Escherichia coli. Sciences des Aliments 10, 62-73.

Manaia, C.M., Nunes, O.C., Morais, P.V. and Costa, M.S. (1990) Heterotrophic plate counts and the isolation of bacteria from mineral waters on selective and enrichment media. Journal of Applied Bacteriology 69, 871-876.

Matin, A., Auger, E.A., Blum, P.H. and Schultz, J.E. (1989) Genetic basis of starvation survival in nondifferentiating bacteria. Annual Reviem of Microbiology 43, 293-316.

Morais, P.V. and da Costa, M.S. (1990) Alterations in the major heterotrophic bacterial populations isolated from a still bottled mineral water. Journal of Applied Bacteriology 69, 750-757.

Morita, R.Y. (1982) Starvation survival of heterotrophs in the marine environment. In Advances in Microbial Ecology ed. Marshall, K.C. Vol. 6, pp. 171-198. New York: Plenum Press.

Overbeek, L.S., van Elsas, J.D., 'Trevors, J.T. and Starodub, M.E. (1990) Long-term survival of and plasmid stability in Pseudomonas and Klebsiella species and appearance of nonculturable cells in agricultral drainage water. Microbial Ecology 19, 239-249.

Pastan, I. and Perlman, R.L. (1968) The role of lac promoter locus in the regulation of $\beta$-galactosidase synthesis by $3^{\prime}, 5^{\prime}-$ adenosine monophosphate. Proceedings of the National Academy of Sciences USA 61, 1336-1342.

Reasoner, D.J. and Geldreich, E.E. (1985) A new medium for the enumeration and subculture of bacteria from potable water. Applied and Environmental Microbiology 49, 1-7.

Roszak, D.B. and Colwell, R. (1987) Survival strategies of bacteria in natural environment. Microbiological Reviems 51, 365-379.

Schmidt-Lorenz, W. (1976) Microbiological characteristics of natural mineral water. Annali dell' Istituto Superiore di Sanita $12,93-112$.

Stewart, M.H. and Olson, B.H. (1992) Impact of growth conditions on resistance of Klebsiella pneumoniae to chloramines. Applied and Environmental Microbiology 5, 2649-2653.

Van der Kooij, D., Orange, J.P. and Hifnen, W.A.M. (1982) Growth of Pseudomonas aeruginosa in tap water in relation to utilization of substrates at concentrations of a few micrograms per liter. Applied and Environmental Microbiology 44, 10861095.

Vess, R.W., Anderson, R.L., Carr, J.H., Bond, W.W. and Favero, M.S. (1993) The colonization of solid PVC surfaces and the acquisition of resistance to germicides by water microorganisms. Journal of Applied Bacteriology 74, 215-221. 